\title{
1. INTRODUCTION, BACKGROUND, AND EXPLANATORY NOTES, DEEP SEA DRILLING PROJECT LEG 94, NORTH ATLANTIC OCEAN ${ }^{1}$
}

\author{
Shipboard Scientific Party ${ }^{2}$
}

\section{BACKGROUND}

In the late 1970 s the advent of hydraulic piston coring from Glomar Challenger provided for the first time a means of extending the fine-scale Quaternary stratigraphy, established from conventional piston coring, through the Neogene. As a result, it became possible to analyze in detail, using paleontological, chemical, and lithological parameters, paleoenvironmental changes spanning millions to tens of millions of years.

Leg 94 represents the last of four transects of sites set up by the Ocean Paleoenvironment Panel to examine climatic and oceanographic changes in the Pacific and Atlantic oceans. Leg 85 drilled an east-west series of sites in the central equatorial Pacific. Legs 86 and 90 drilled latitudinal transects in the northwest and southwest $\mathrm{Pa}$ cific, respectively.

During Leg 94, a transect of six holes aligned roughly in a south-southwest/north-northeast direction were drilled in the North Atlantic from $37^{\circ}$ to $53^{\circ} \mathrm{N}$ (Fig. 1; Table 1). The principal objective of this transect was to document the magnitude and spectral character of the surface-ocean response to high-latitude climatic change in the northern hemisphere during the Neogene. Changes in the modes of oceanic response in this highly sensitive region could then be traced from the late Quaternary record, documented from piston coring, back into times of significantly different climatic boundary conditions (no northern hemisphere ice sheets, an open Panamanian Isthmus, a closed Gibraltar Isthmus, a smaller Antarctic ice sheet). Ancillary paleoclimatic objectives included the

\footnotetext{
${ }^{1}$ Ruddiman, W. F., Kidd, R. B., Thomas, E., et al., Init. Repts. DSDP, 94: Washington (U.S. Govt. Printing Office)

2 William F. Ruddiman (Co-Chief Scientist), Lamont-Doherty Geological Observatory, Dept. of Geological Sciences, Columbia University, Palisades, NY 10964; Robert B. Kidd (Co-Chief Scientist), Institute of Oceanographic Sciences, Surrey GU8 SUB, United Kingdom (present address: Ocean Drilling Program, Texas A\&M University, College Station, TX 77843. 3469); Ellen Thomas (Science Representative), Deep Sea Drilling Project Scripps Institution of Oceanography, La Jolla, CA (present address: Lame Dept. of Ceological Sciences, Columbia University, Palisades, NY 10964); Jack G. Baldauf, Paleontology and Stratigraphy Branch, U.S. Geological Survey, Menlo Park, CA (present address: Ocean Drilling Program, Texas A\&M University, College Station, TX 77843-3469); Bradford M. Clement, Lamont-Doherty Geological Observatory, Palisades, NY (present address: Ocean Drilling Program, Texas A\&M University, College Station, TX 77843-3469); James F. Dolan, Dept, of Earth Sciences, University of California, Santa Cruz, Santa Cruz, CA 95060; Margaret R. Eggers, Dept, of Geology, University of South Carolin, Columb, SC 29208; Philip R. Hill, Atlantic Geoscience Cent Unit Geological Survey of Cana, Bedford Institute of Oceanography, Dartmouth, Nova Scotia B2Y 4A2 Canada; Lloyd D. Keigwin, Ir., Dept. of Geology and Geophysics, Woods Hole Oceanographic Institution, Woods Hole, MA 02543; Margie Mitchell, Geological Research Div., Scripps Institution of Oceanography, La Jolla, CA 92093; Isabelle Philipps, Laboratoire de Géologie et Océanographie, Université de Bordeaux 1, 33605 Talence Cedex France; Frank Robinson, Lamont-Doherty Geological Observatory, Palisades, NY 10964; Sassan A. Salehipour, Ocean Engineering No. 2, University of Rhode Island, Kingston, RI 02882; Toshiaki Takayama, Dept. of Geology, Kanazawa University, Kanazawa 920 Japan; Gerhard Unsold Geologisch-Paläontologisches Institut, Univer Universitat Kiel, D-2300 Kiel, Kederal Republic of Germany; Philip Oceanographic Sciences, Surrey GU8 5UB, United Kingdom.
}

recovery of both a faunal and an isotopic record of deepwater variations at water depths ranging from 2393 to $3871 \mathrm{~m}$.

Other major targets sought as well as the basic paleoclimatic objectives included ascertaining (1) the Neogene history of accelerated sediment deposition on the Feni Ridge in Rockall Trough and the Gardar Ridge on the east flank of the Mid-Atlantic Ridge; and (2) the tectonic history of the King's Trough complex north of the Azores. In addition, rotary or extended core barrel drilling at Site 608 below the upper Neogene hydraulic piston coring objectives attempted to fill gaps in the global DSDP stratigraphic array of Eocene-Oligocene sediment cores. Other significant objectives included establishing (1) a record of Neogene paleomagnetic stratigraphy including detailed polarity transitions; (2) sequences defining variations in the input of continental detritus, particularly by ice rafting; and (3) a Neogene $\mathrm{CaCO}_{3}$ dissolution history for the North Atlantic.

\section{CRUISE OBJECTIVES}

\section{Neogene Paleoclimatology}

The surface North Atlantic from $40^{\circ}$ to $50^{\circ} \mathrm{N}$ has been the most thermally reactive oceanic area in the world during the late Quaternary, undergoing glacial-interglacial oscillations of sea-surface temperature (SST) in excess of $12^{\circ} \mathrm{C}$ (Fig. 2). The frequency characteristics of this response change dramatically across the $1800-\mathrm{km}$ span of latitudes cored on Leg 94 . South of $45^{\circ} \mathrm{N}$, the dominant periodicities are 23,000 and $100,000 \mathrm{yr}$; north of that latitude, they are 100,000 and 41,000 yr. (Figs. 2 and 3). The concentrations of spectral power in the SST records at these three orbital frequencies are as high as any observed on the face of the Earth.

The North Atlantic is a region critically located for climatic interactions, both with the surrounding ice-age ice sheets and with the overlying atmosphere. Several climatic theories call on this part of the ocean for important feedback interactions that amplify global climatic changes initially driven by orbital variations.

The interactions and feedbacks typical of the last several hundred thousand years of the Quaternary can be expected to have been different in the geologic past, both during the smaller pre-Brunhes oscillations of the Northern Hemisphere ice sheets and during the early Pliocene and late Miocene ice-free conditions in the Northern Hemisphere. This leg was designed to detect both the changes in boundary conditions (ice-sheet size, as determined from oxygen isotopes and ice-rafted detritus) and in oceanic response (as determined from planktonic microfossils). 


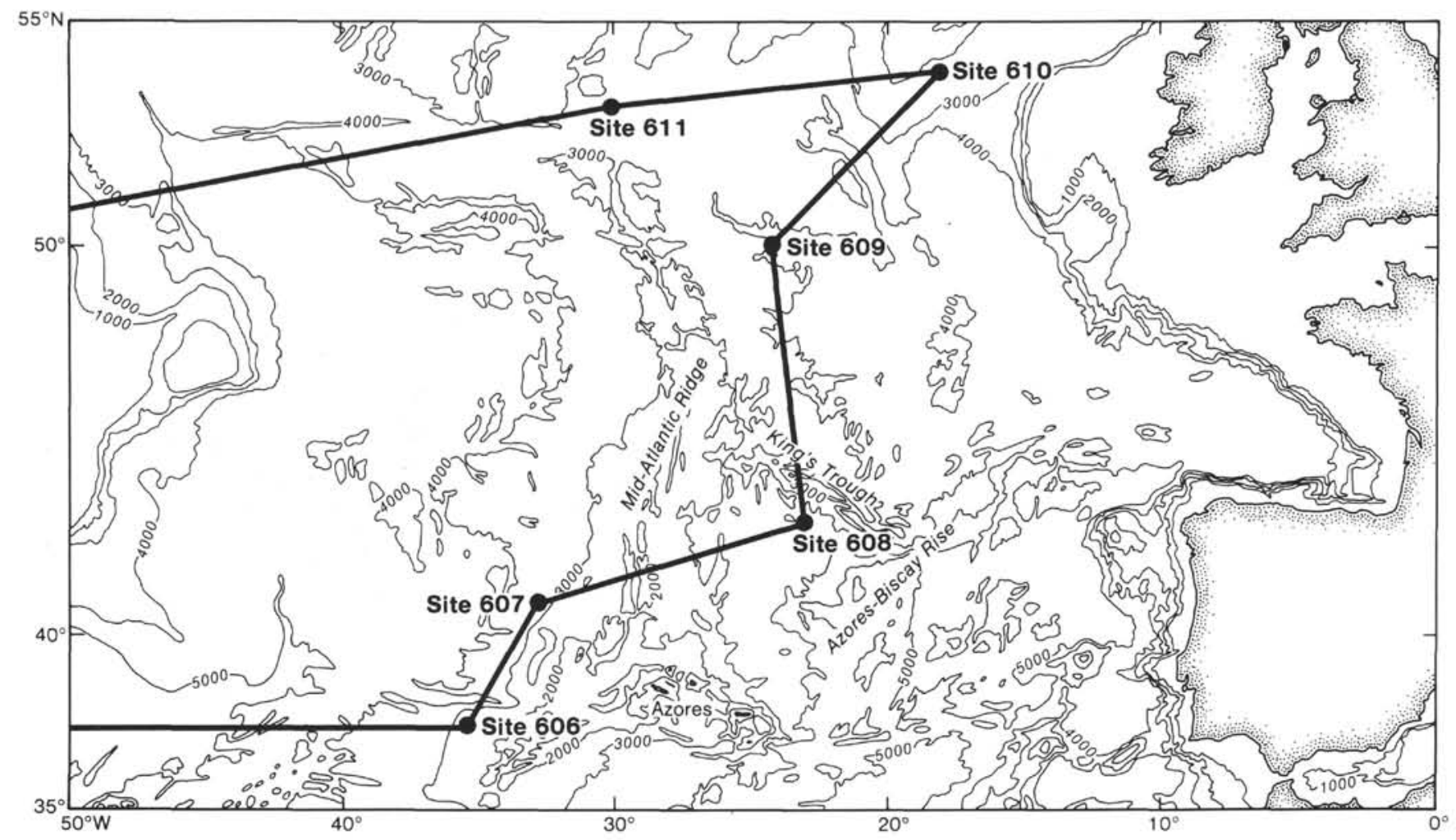

Figure 1. Leg 94 track and site locations; bathymetry in meters (after Kidd et al., 1982).

Table 1. Summary of Leg 94 drilling.

\begin{tabular}{|c|c|c|c|c|c|c|c|c|c|}
\hline Hole & Dates (1983) & Latitude & Longitude & $\begin{array}{l}\text { Water } \\
\text { depth }^{\mathrm{a}}\end{array}$ & Penetration & $\begin{array}{l}\text { No. of } \\
\text { cores }\end{array}$ & $\begin{array}{l}\text { Meters } \\
\text { cored }\end{array}$ & $\begin{array}{l}\text { Meters } \\
\text { recovered }\end{array}$ & $\begin{array}{l}\text { Percent of } \\
\text { recovery }\end{array}$ \\
\hline 606 & 2-4 July & $37^{\circ} 20.32^{\prime} \mathrm{N}$ & $35^{\circ} 29.99^{\prime} \mathrm{W}$ & 3007 & 165.8 & 18 & 165.8 & 154.1 & 93 \\
\hline 606A & 4-5 July & $37^{\circ} 20.29^{\prime} \mathrm{N}$ & $35^{\circ} 30.02^{\prime} \mathrm{W}$ & 3007 & 178.4 & 19 & 178.4 & 156.3 & 88 \\
\hline 607 & 6-9 July & $41^{\circ} 00.07^{\prime} \mathrm{N}$ & $32^{\circ} 57.44^{\prime} \mathrm{W}$ & 3427 & 284.4 & 30 & 284.4 & 248.2 & 87 \\
\hline $607 \mathrm{~A}$ & 9-11 July & $41^{\circ} 00.07^{\prime} \mathrm{N}$ & $32^{\circ} 57.44^{\prime} \mathrm{W}$ & 3427 & 311.3 & 26 & 226.6 & 205.0 & 91 \\
\hline 608 & 13-17 July & $42^{\circ} 50.21^{\prime} \mathrm{Q}$ & $23^{\circ} 05.25^{\prime} \mathrm{W}$ & 3526 & 530.3 & 59 & 530.3 & 428.0 & 81 \\
\hline $608 \mathrm{~A}$ & 17-18 July & $42^{\circ} 50.21^{\prime} \mathrm{N}$ & $23^{\circ} 05.25^{\prime} \mathrm{W}$ & 3526 & 146.4 & 16 & 146.4 & 144.0 & 98 \\
\hline 609 & 22-23 July & $49^{\circ} 52.67^{\prime} \mathrm{N}$ & $24^{\circ} 14.29^{\prime} \mathrm{W}$ & 3884 & 399.4 & 42 & 399.4 & 301.2 & 75 \\
\hline $609 \mathrm{~A}$ & 23 July & $49^{\circ} 52.67^{\prime} \mathrm{N}$ & $24^{\circ} 14.29^{\prime} \mathrm{W}$ & 3883 & 43.0 & 2 & 19.2 & 17.9 & 93 \\
\hline $609 \mathrm{~B}$ & 23-26 July & $49^{\circ} 52.67^{\prime} \mathrm{N}$ & $24^{\circ} 14.29^{\prime} \mathrm{W}$ & 3883 & 354.7 & 38 & 354.7 & 308.4 & 87 \\
\hline 610 & 28-31 July & $53^{\circ} 13.30^{\prime} \mathrm{N}$ & $18^{\circ} 53.21^{\prime} \mathrm{W}$ & 2417 & 723.0 & 27 & 259.2 & 179.3 & 69 \\
\hline $610 \mathrm{~A}$ & 31 July-1 Aug. & $53^{\circ} 13.30^{\prime} \mathrm{N}$ & $18^{\circ} 53.21^{\prime} \mathrm{W}$ & 2417 & 201.0 & 21 & 201.0 & 191.4 & 95 \\
\hline $610 \mathrm{~B}$ & 1-2 August & $53^{\circ} 13.30^{\prime} \mathrm{N}$ & $18^{\circ} 53.21^{\prime} \mathrm{W}$ & 2417 & 146.8 & 16 & 146.8 & 136.3 & 93 \\
\hline $610 \mathrm{C}$ & 2-3 August & $53^{\circ} 13.30^{\prime} \mathrm{N}$ & $18^{\circ} 53.21^{\prime} \mathrm{W}$ & 2417 & 118.2 & 6 & 48.4 & 43.9 & 91 \\
\hline $610 \mathrm{D}$ & 3 August & $53^{\circ} 13.47^{\prime} \mathrm{N}$ & $18^{\circ} 53.69^{\prime} \mathrm{W}$ & 2445 & 386.8 & 7 & 66.0 & 54.2 & 82 \\
\hline $610 \mathrm{E}$ & 3-4 August & $53^{\circ} 13.47^{\prime} \mathrm{N}$ & $18^{\circ} 53.69^{\prime} \mathrm{W}$ & 2445 & 327.2 & 7 & 67.2 & 53.3 & 79 \\
\hline 611 & 6-7 August & $52^{\circ} 50.47^{\prime} \mathrm{N}$ & $30^{\circ} 18.58^{\prime} \mathrm{W}$ & 3203 & 125.8 & 14 & 125.8 & 112.2 & 89 \\
\hline $611 \mathrm{~A}$ & 7-8 August & $52^{\circ} 50.47^{\prime} \mathrm{N}$ & $30^{\circ} 18.58^{\prime} \mathrm{W}$ & 3201 & 132.0 & 14 & 132.0 & 99.4 & 75 \\
\hline $611 \mathrm{~B}$ & 8 August & $52^{\circ} 50.15^{\prime} \mathrm{N}$ & $30^{\circ} 19.10^{\prime} \mathrm{W}$ & 3228 & 8.9 & 1 & 8.9 & 8.9 & 100 \\
\hline $611 \mathrm{C}$ & 8-11 August & $52^{\circ} 50.15^{\prime} \mathrm{N}$ & $30^{\circ} 19.10^{\prime} \mathrm{W}$ & 3230 & 511.6 & 47 & 434.8 & 344.1 & 79 \\
\hline 611D & 11-12 August & $52^{\circ} 50.47^{\prime} \mathrm{N}$ & $30^{\circ} 18.58^{\prime} \mathrm{W}$ & 3195 & 244.1 & 14 & 124.8 & 122.3 & 98 \\
\hline \multirow[t]{2}{*}{$611 \mathrm{E}$} & 12 August & $52^{\circ} 50.47^{\prime} \mathrm{N}$ & $30^{\circ} 18.58^{\prime} \mathrm{W}$ & 3195 & 25.7 & 2 & 19.2 & 19.2 & 100 \\
\hline & & & & & & & 3939.3 & 3327.6 & 84 \\
\hline
\end{tabular}

${ }^{a}$ At sea level.

The six-site transect shown in Figure 1 was positioned in such a way as to span the major part of the region of large-scale ice-age thermal response (Fig. 2). The three southern sites are in the region now dominated by the 23,000- and 100,000-yr. response, with the amplitude building from around $6^{\circ} \mathrm{C}$ at the southernmost site (Site 606) to over $12^{\circ} \mathrm{C}$ at the next two sites to the north (Sites 607 and 608). The three northernmost sites are in re- gions now dominated by 100,000 - and 41,000 -yr. cycles, with the largest amplitude $\left(13^{\circ} \mathrm{C}\right)$ at Site $609\left(49^{\circ} 52^{\prime} \mathrm{N}\right)$ and somewhat diminished amplitudes at Sites 610 and 611 farther to the north.

Because of the thick sequences of carbonate ooze and interbedded glacial marine sediments deposited at rapid rates $(30-100 \mathrm{~m} / \mathrm{m} . \mathrm{y}$.) in the area, Leg 94 retrieved a valuable record of late Neogene stratigraphy, with one 


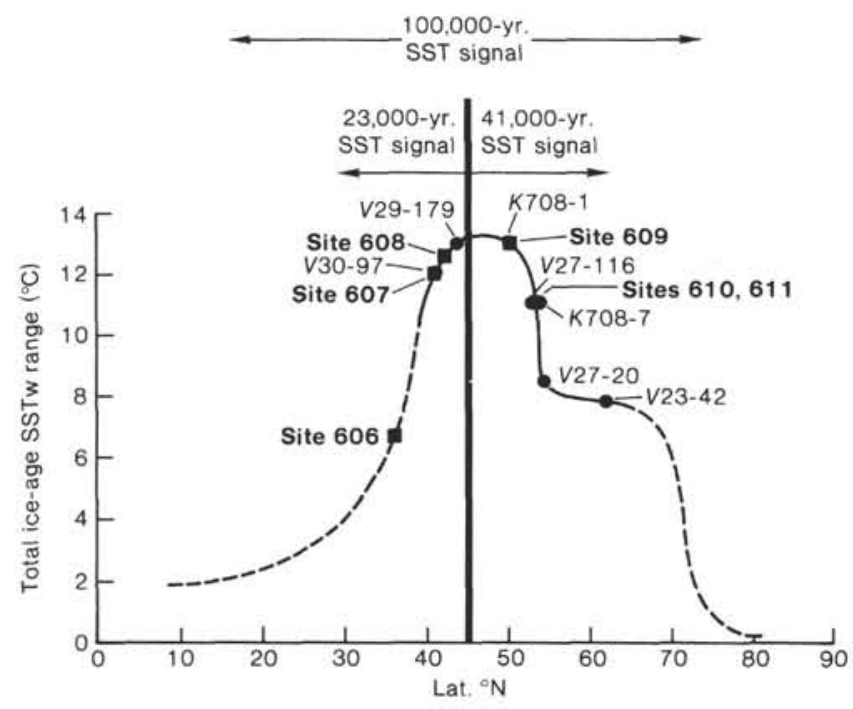

Figure 2. Placement of Leg 94 sites along a north-south transect showing: (1) total amplitude of glacial-interglacial sea-surface temperature (SST) change during the late Quaternary (Brunhes Epoch), and (2) relative apportioning of that change among the three orbital periodicities $(23,000,41,000$, and $100,000 \mathrm{yr}$.) that dominate these records. (Piston cores are shown from Vema $(\mathrm{V})$ and Conrad $(K)$ cruises; SSTw-sea-surface temperature, winter.)

site (Site 608) reaching back to Eocene sediments. Finally, with coring across a 1000 -km-long transect and over a water depth range of $1500 \mathrm{~m}$, these sediments should contain significant information on deep-water flow based on $\delta^{18} \mathrm{O}, \delta^{13} \mathrm{C}$, and benthic foraminiferal assemblages. Four holes are situated on the eastern flank of the Mid-Atlantic Ridge and two high on the west flank (Fig. 1).

\section{Sediment Deposition on Feni and Gardar Ridges}

Site 552 drilled during Leg 81 on the edge of Hatton Drift was the first hydraulic-piston core site with a highresolution stratigraphy to be taken from a region of positive sediment accumulation controlled by bottom currents. Site 610 , located on the crest of Feni Ridge in Rockall Trough, was targeted to recover a Miocene-toQuaternary sequence of current-deposited sediments in order to improve the present constraints on the date of initiation of drift sedimentation in that area. The site was also targeted to allow us to detect hiatuses caused by accelerated bottom flow and to characterize lithologies typical of the most rapidly accumulating sediments of a large sedimentary drift. Site 611 , located on the southern tip of Gardar Ridge but still within an area of sediment waves that are the common ornamentation on the surface of major drifts, had similar stratigraphical and sedimentological objectives.

\section{Tectonic History of King's Trough}

Site 608 is located near the King's Trough complex, a positive bathymetric region marked by a long chain of parallel ridges and basins (Fig. 1). The most plausible of several hypotheses put forward to explain this unusual topographic feature postulates (1) formation of the crust, between 56 and $21 \mathrm{Ma}$, by development of an aseismic
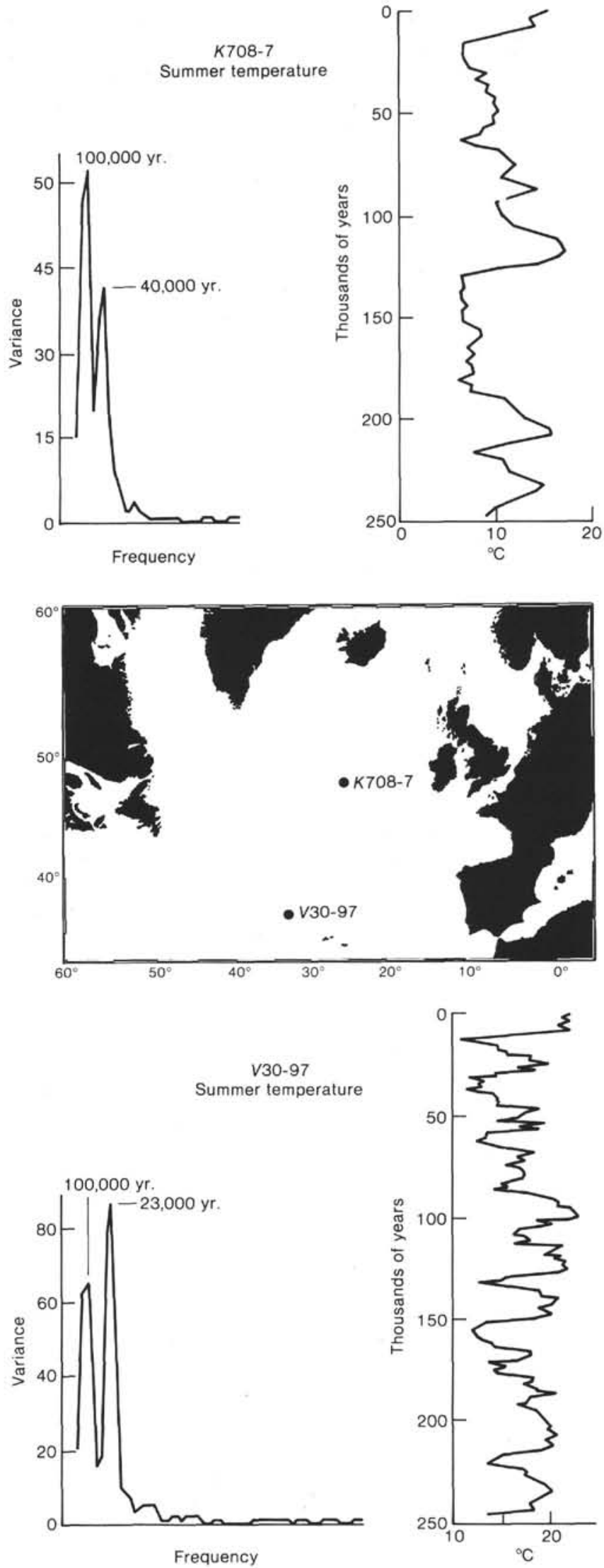

Figure 3. Late Quaternary sea-surface temperature (SST) frequency response in piston cores $V 30-97$ (near Site 607) and K708-7 (near Site 611). 
ridge from a portion of the Mid-Atlantic Ridge made anomalously shallow by the presence of a hot spot; (2) a sudden uplift of up to $2 \mathrm{~km}$ at roughly $32 \mathrm{Ma}$; (3) rifting with extensional downdropping of 2 to $4 \mathrm{~km}$ at roughly 16 to $20 \mathrm{Ma}$, and (4) normal subsidence to the present.

Continuous coring at Site 608 on the western flank of King's Trough away from the region of vertical tectonics was expected to recover a stratigraphic sequence in which nearby volcanic episodes and tectonically produced hiatuses could be detected. This would provide a comprehensive stratigraphy into which dredge and rock core data obtained in the central tectonic zone could be placed.

\section{EXPLANATORY NOTES}

\section{Drilling Techniques}

There are several types of coring systems on the Glomar Challenger: (1) the standard DSDP rotary-coring system, which cuts about 9.5 -m-long cores and has been used since Leg 1; (2) the Extended Core Barrel system (XCB), which has been used extensively since Leg 90 (see Kennett, von der Borch, et al., 1986), and (3) the Hydraulic Piston Coring system (HPC), used since Leg 64 (Fig. 4). This coring system is described in Prell, Gardner, et al. (1982). A variation on the HPC system is the Variable Length Hydraulic Piston Coring system (VLHPC), which has been used since Leg 85 (see Mayer, Theyer, et al., 1985), and the Advanced Piston Coring system (APC), used first on Leg 94.

The APC takes a $9.5-\mathrm{m}$ core and utilizes the same technology as the Variable Length Hydraulic Piston Corer (VLHPC) (Fig. 4). The APC, however, incorporates a simplified seal system that results in a piston corer capable of $80 \%$ greater coring force (up to $28,000 \mathrm{lbf}$-pounds force), but that is about half as mechanically complex as the VLHPC. The main difference is the use of the dynamic seal acting between the scoping core barrel section and a special honed-bore drill collar.

The APC consists of two basic sections. The top sub, piston rod, and piston head comprise the static section. The scoping core barrel section is initially pinned to the static section with from one to three shear pins.

The APC is lowered down the drill pipe to land and seal on the special drill collar. When the drill string above the seal is pressurized, the pressure acts on the scoping section through the speed control holes in the top sub, into which set screws can be added or removed to control coring velocity.

Other features include: (1) An optional breakaway piston head to minimize core disturbance in those instances where the APC fails to achieve full stroke. (2) The ability to withstand safely tensile loads of up to $100,000 \mathrm{lbf}$. In stiff or adhering formations a large suction force resists tool withdrawal. Several times the VLHPC has been literally pulled apart with $80,000 \mathrm{lbf}$ over-pull. (3) An axial groove has been machined down the length of the piston rod. This engages a key in the scoping core barrel section to prevent the core barrel from rotating as it injects into the formation. (4) The APC is about 38 feet long compared to the 70-foot-long VLHPC. The shorter length makes it much easier to handle, and opens up the possibility for piston coring with the Heave Compensator in-line.

The APC was used on Holes 606 and 606A. Aside from some initial start-up problems inherent with any new tool, the APC was very successful on Hole 606. In particular, the tool was much easier to handle; we were able to penetrate further than would have been possible with the VLHPC in the stiff, sticky nannofossil ooze encountered. In Hole 606A, 100,000 lbf. over-pull was needed to retrieve Core 18 . While attempting to retrieve Core 20 , the piston rod connection broke at $40,000 \mathrm{lbf}$. overpull. The failure was probably due to fatigue initiated during the previous high pull. The failure is being studied with the intention of strengthening this weak link. In any event, even if a limitation of 50,000 lbf. over-pull is imposed, the APC is a capable successor to the VLHPC.

No further APC coring was possible at the later Leg 94 sites because of the loss of the lower section.

\section{Handling of Cores}

A core is normally cut into $1.5-\mathrm{m}$ sections, sealed, labeled, and then brought into the core laboratory for processing. Continuous wet-bulk density determinations are made using the GRAPE before splitting the plastic liner.

The cores are then split longitudinally into "working" and "archive" halves. Samples are taken from the "working" half, including those for determination of sonic velocity by the Hamilton Frame method, wet-bulk density by a static GRAPE technique, water content by gravimetric analysis, calcium-carbonate percentage (carbonate bomb), geochemical analysis, paleontological studies, and so on.

Smear slides (thin sections for lithified sedimentary and igneous rocks) from each major lithology and most minor lithologies are prepared and examined microscopically. The archive half is then described and photographed. Physical disturbances, color, texture, structures, and composition of the various lithologies are noted on standard core description forms (Fig. 5). All prime data are routinely microfilmed and some are digitized for computer retrieval.

After the cores are sampled and described, they are maintained in cold storage aboard the Glomar Challeng$e r$ until they are transferred to the DSDP repository. Core sections of sediments removed for organic geochemistry study are frozen immediately aboard ship and kept frozen. All Leg 94 cores are presently stored at the DSDP East Coast Repository (Lamont-Doherty Geological Observatory of Columbia University).

\section{Numbering of Sites, Holes, Cores, and Samples}

DSDP drill sites are numbered consecutively from the first site drilled by Glomar Challenger in 1968. Site numbers are slightly different from hole numbers. A site number refers to one or more holes drilled while the ship is positioned over one acoustic beacon; these holes can be located within a radius as great as $900 \mathrm{~m}$ from the beacon. Several holes may be drilled at a single site by pulling the drill pipe above the seafloor (above one hole), moving the ship $100 \mathrm{~m}$ or more from the previous hole, and then drilling another hole. 
1

$\mathrm{HPC}$ is seated and seawater pumped at $350 \mathrm{gpm}$ to actuate
2

Locking pins shear at $1700 \mathrm{psi}$

pressure on travelling piston

drives core tube; fluid above

stationary piston is vented;

core tube speed is approximately

$10-20$ feet per second

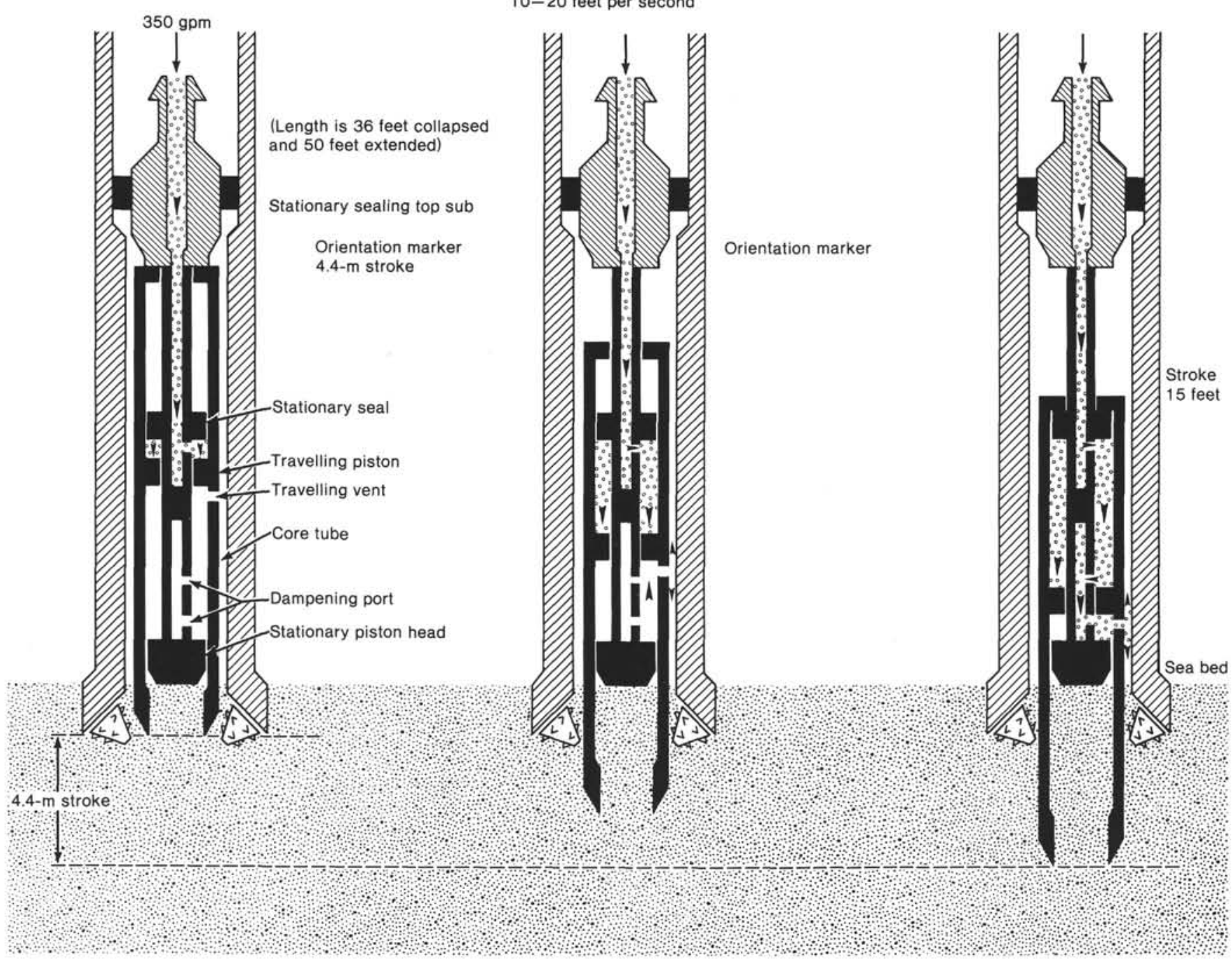

At the end of the stroke. dampening ports are uncovered to vent the pressure fluid and decelerate the core

Figure 4. Operational sequence for the Serocki-Storms-Cameron DSDP Hydraulic Piston Corer.

The first (or only) hole drilled at a site takes the site number. A letter suffix distinguishes each additional hole at the same site. For example, the first hole takes only the site number, the second takes the site number with suffix A, the third takes the site number with suffix B, and so on. It is important, for sampling purposes, to distinguish the holes drilled at a site, because recovered sediments or rocks from different holes usually do not come from equivalent positions in the stratigraphic column.

The cored interval is measured in meters below the seafloor. The depth interval of an individual core spans from the depth below seafloor at which the coring began to the depth at which coring ended. The nominal coring interval is $9.5 \mathrm{~m}$ long during rotary drilling and for the long barrel of the VLHPC. It is $5 \mathrm{~m}$ for the short barrel. In practice, these nominal coring intervals may be shorter or slightly longer.

Cored intervals are not necessarily adjacent to each other, but may be separated by drilled intervals. In soft sediment the drill string can be "washed ahead": that is, the core barrel is in place, but does not recover sediment. This is achieved by pumping water down the pipe at high pressure, which washes the sediment out of the way of the bit, up the space between the drill pipe and the wall of the hole. During this procedure it is possible to get "spotty" sampling of resistant layers, and thus recover a cored interval greater than $9.5 \mathrm{~m}$.

When full, a core normally recovers $9.28 \mathrm{~m}$ of sediment or rock in a plastic liner of 6.6-cm I.D. In addition, about $0.2 \mathrm{~m}$ of sample (no plastic liner) is in the core catcher. (The core catcher is a device at the bottom 


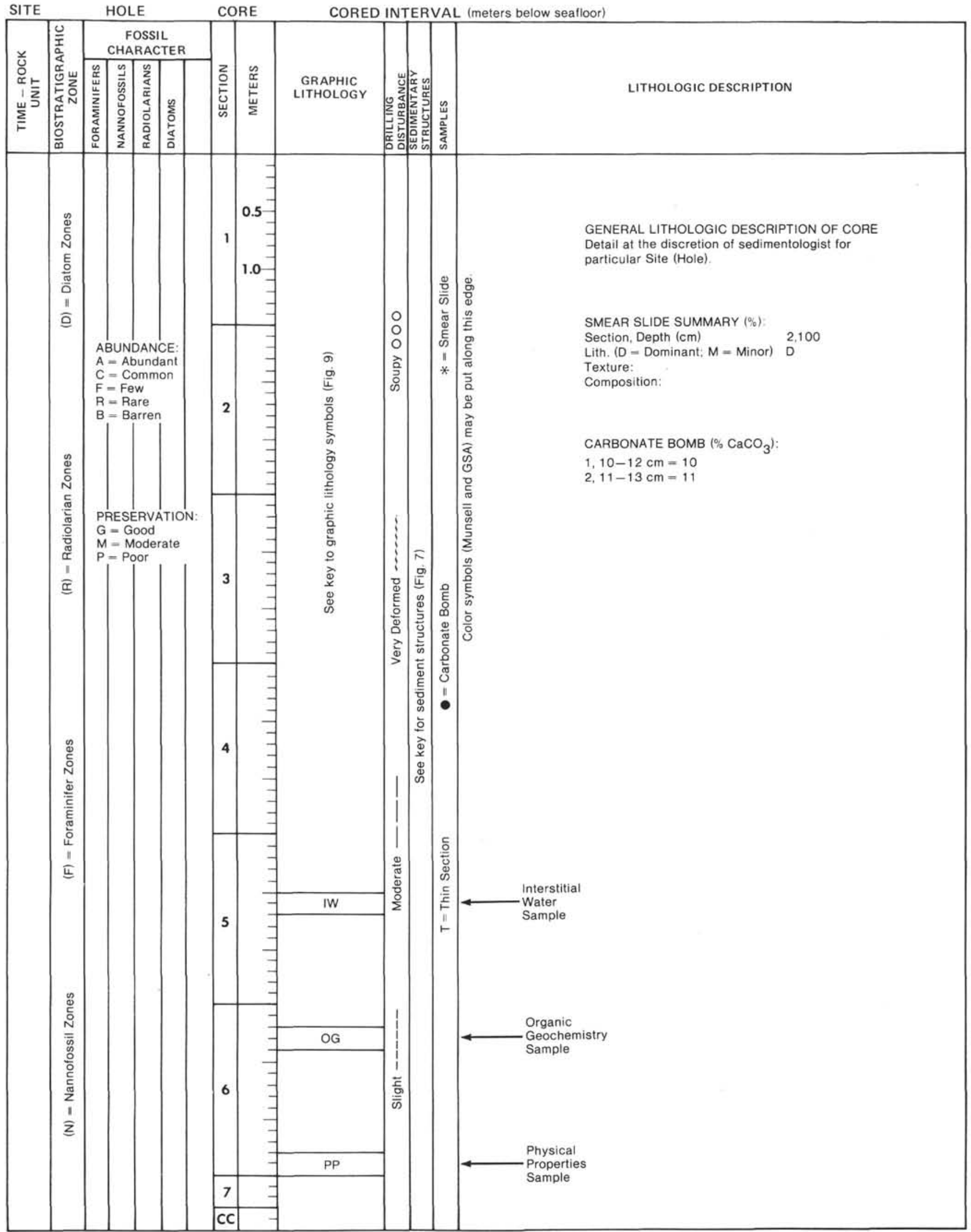

Figure 5. Standard core description form (sediment). 
of the core barrel that prevents the cored sample from sliding out when the barrel is being retrieved from the hole.) With the short barrel of the VLHPC, about $4.75 \mathrm{~m}$ are collected when it is full, and about $0.2 \mathrm{~m}$ of corecatcher sample.

Each core is then cut into 1.5 -m-long sections, which are numbered serially from the top of the core (Fig. 6). When there is full recovery, the sections are numbered 1 through 7 for the rotary-drilled and long-barrel-of-theVLHPC cores, and 1 through 4 for short-barrel-of-theVLHPC cores (the last section being shorter than 1.5 $\mathrm{m})$. The core-catcher sample is placed below the last section when the core is described, and labeled core catcher (CC); it is treated as a separate section.

In the case of partial recovery, the original stratigraphic position of the sediment in the cored interval is unknown. If the recovered rocks and sediments are contiguous, the top of this material becomes the top of the cored interval. Sections are numbered serially from the top, beginning with Section 1 (Fig. 6), to accommodate the length of the recovered sediment. For example, $4 \mathrm{~m}$ of sediment are divided into three sections-two upper 1.5 -m-long sections and a lower $1-\mathrm{m}$ section. If the sediment is determined to be discontinuous by the shipboard scientists, sections are divided and numbered serially, but gaps are labeled "voids" (Fig. 6) or marked with spacers in igneous sections.

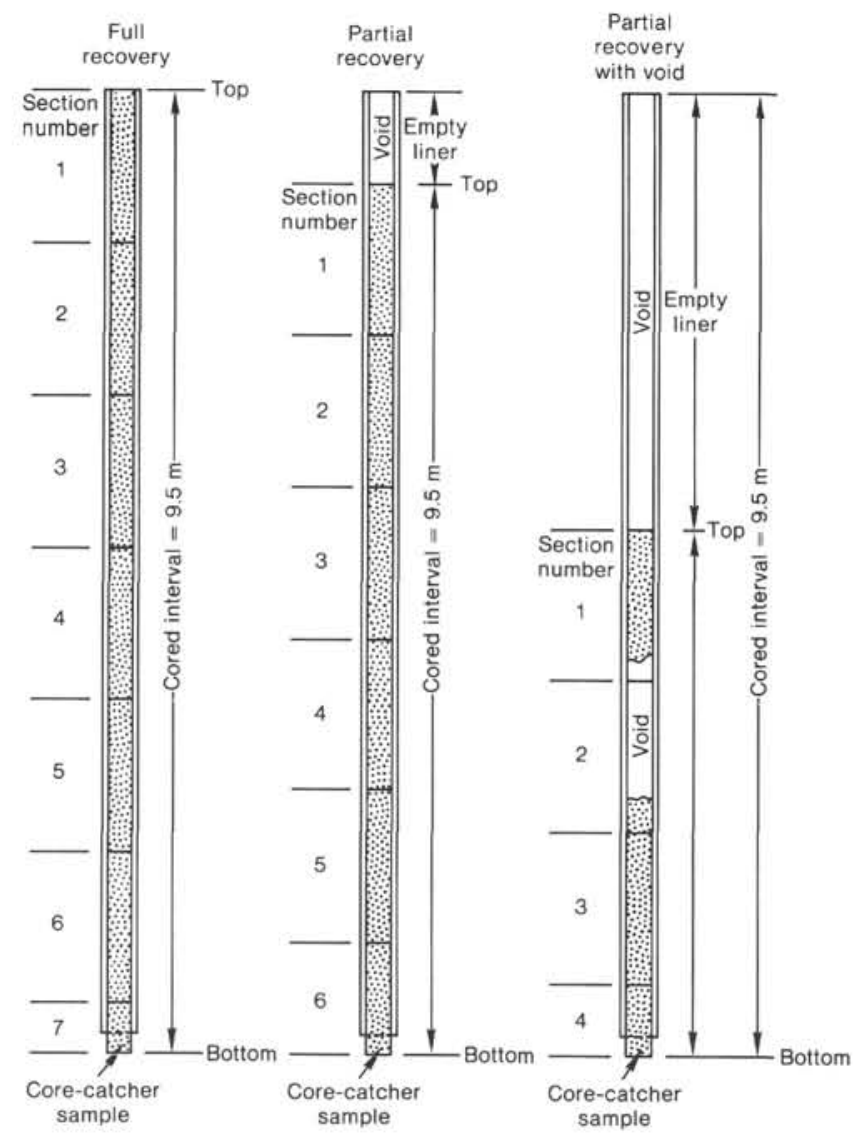

Figure 6. Diagram showing procedure for cutting and labeling core sections.
Cores taken from a hole are numbered serially from the top of the hole downward. Thus core numbers and their associated cored interval in meters below the seafloor are normally unique for a hole; however, problems may arise if an interval is cored twice.

A sample is designated by the interval in centimeters that it spans as measured from the top of the section from which it is taken. A full identification number for a sample consists of the following information: leg-site (or hole)-core number-section number, interval in centimeters from the top of the section. For instance, a sample identification number of " $85-610 \mathrm{~A}-12-3,12-14 \mathrm{~cm}$ " is interpreted as follows: this sample was taken between 12 and $14 \mathrm{~cm}$ from the top of Section 3 of Core 12, from the second hole drilled at Site 610 during Leg 94. A sample from the core catcher of this core is designated as "94-610A-12,CC."

\section{Obtaining Samples}

Potential investigators who desire to obtain samples should refer to the DSDP-NSF Sample Distribution Policy (see the Table of Contents). Sample request forms may be obtained from the Curator, Ocean Drilling Program, Texas A\&M University, College Station, Texas 77843. Requests must be as specific as possible and include site, core, section, interval within a section, and volume of samples required.

\section{Core Description Forms}

The notes below explain the standards used by the Leg 94 sedimentologists in describing the cores and filling out the core description forms for each site.

\section{Core Disturbance}

Recovered rocks and particularly soft sediments may be extremely disturbed as a result of coring techniques. The following categories of disturbance are used for soft to firm sediments: (1) slightly deformed-bedding contacts are slightly bowed; (2) moderately deformed-bedding contacts are extremely bowed and firm sediment is fractured; (3) very deformed-bedding is completely disturbed or is homogenized by drilling and may show diapirlike structures; (4) soupy-water saturated intervals that have lost all aspects of original bedding; (5) drill biscuits: firm sediments may be broken into discrete pieces that are probably rotated but maintain their stratigraphic integrity relative to one another; these blocks are often surrounded by brecciated or flowed sediments. These categories are listed on the core description forms in the column headed "Drilling Disturbance" (Fig. 5).

\section{Sedimentary Structures}

It is often extremely difficult to distinguish natural structures from those created by coring. Description of sedimentary structures is optional. Locations and types of these structures appear as graphic symbols in the column headed "Sedimentary Structures" (Fig. 7).

Bioturbation is difficult to recognize in monotonous white to pale gray oozes. Where obvious, the degree of burrowing was noted and occasionally the type of burrow was included in the lithologic description portion of 


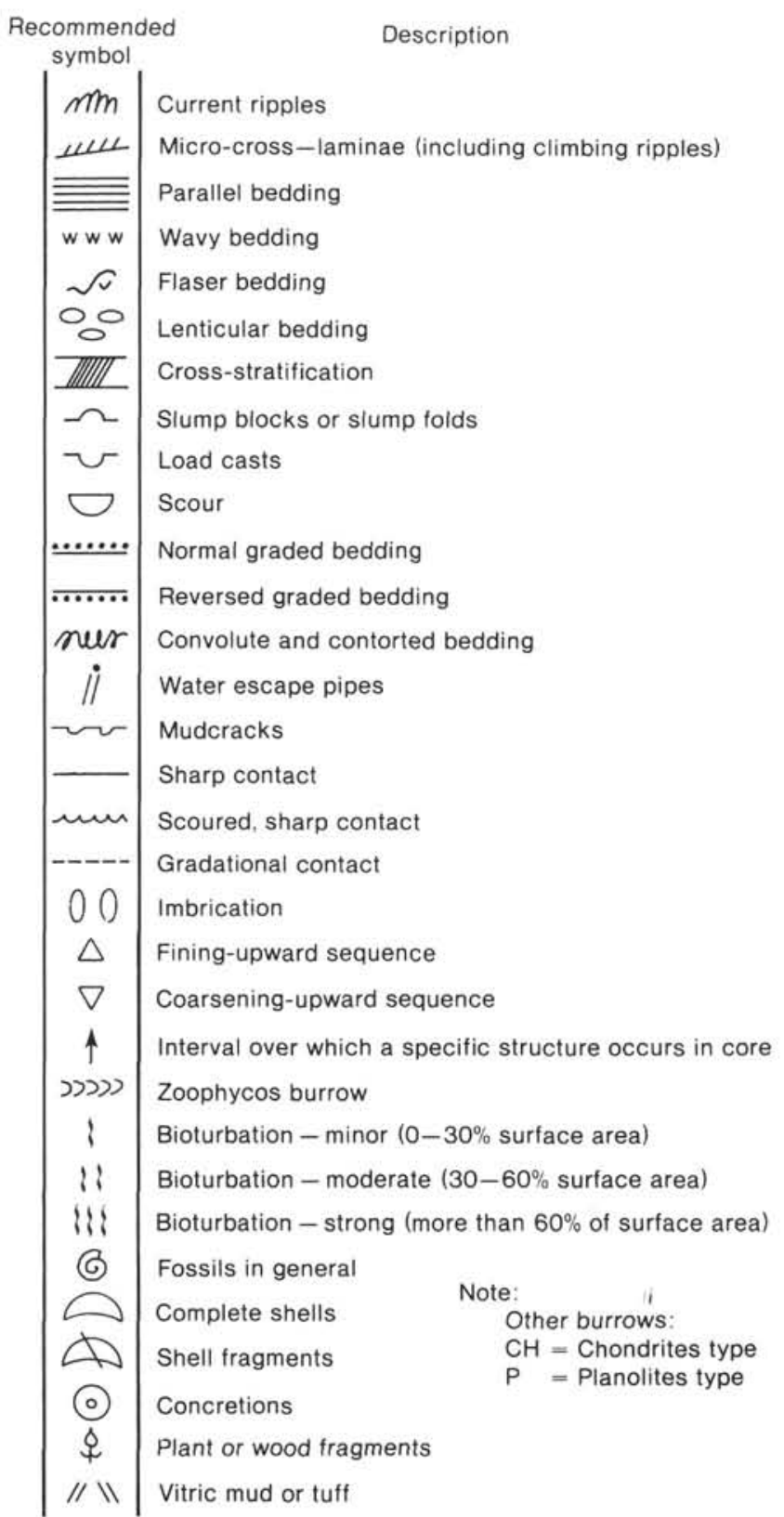

Figure 7. Symbols for sedimentary structures noted on core descriptions forms (sediment).

the core description forms. The types of burrows are illustrated in Figure 8.

\section{Color}

Sediment and rock color is determined using a Munsell or Geological Society of America rock-color chart. Colors were determined immediately after the cores were split and still wet.

\section{Lithology}

The graphic column presented on the core description form represents the lithology by means of one or more patterns. The symbols correspond to end-member sediment constituents such as clay or nannofossil ooze. The pattern for terrigenous constituent(s) appears on the

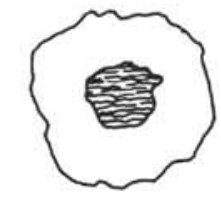

Hollow Cylindrichnus

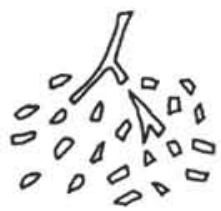

Chondrites

DDDDDDDDDDDDDDDD

Simple Zoophycos

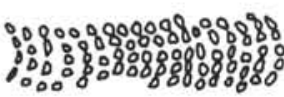

Pelleted Zoophycos

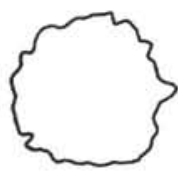

Solid Cylindrichnus

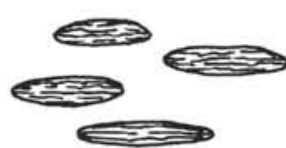

Planolites

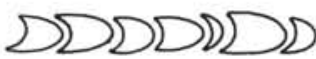

Fat Zoophycos

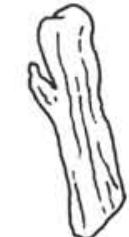

Pyrite Burrows
Figure 8. Common trace fossils in DSDP cores.

left-hand side of the column. The pattern for the biogenic constituent(s) appears on the right-hand side of the column. The abundance of any component approximately equals the percentage of the width of the graphic column its symbol occupies. For example, the right $20 \%$ of the column may have a nannofossil ooze symbol, whereas the left $80 \%$ of the column may have a mud symbol-indicating sediment composed of $80 \%$ mud and $20 \%$ nannofossils.

Because of the difference in the length-to-width ratio between the sediment core and the graphic lithologic column it is not possible to reproduce structures as they appear in the core because they become highly flattened and distorted. The same is true for rock fragments or pebbles in the cores. As a result, the locations of pebbles are shown by a solid square and the depth of small "patches" of ash or other lithologic changes is given by a triangular inset of the appropriate lithologic symbol on the right side of the lithologic column (Fig. 9). This convention applies only to lithologies which do not extend across the entire core.

The assignment of sediment name is controlled by the DSDP mandatory graphic lithologic column scheme (Figs. 5, 7-9). Colors and additional information such as structures (Fig. 7) or texture (Fig. 9) are included in the text portion of the core description. The descriptive portions of the core description forms were written in- 
INTRODUCTION, BACKGROUND, AND EXPLANATORY NOTES

Pelagic

Nonbiogenic

Pelagic clay

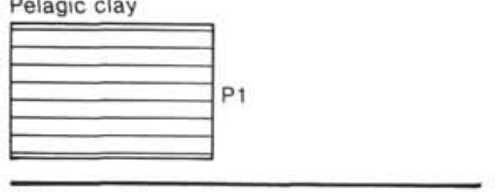

Siliceous biogenic

Pelagic siliceous biogenic - soft

Diatom ooze

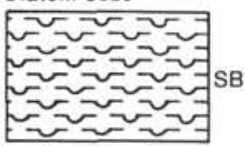

Pelagic siliceous biogenic - hard

Diatomite

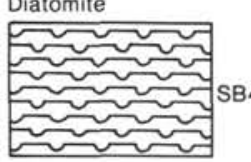

Radiolarian ooze

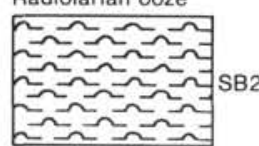

Vertical bar percent

(\%) designation for

graphic log

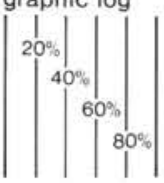

Diatom-radiolarian

or siliceous ooze

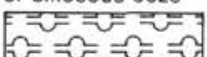

$=\Omega \Omega=-$ : SB3

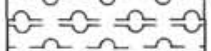

$E \cap 2 \Omega=\Omega^{2}=1$

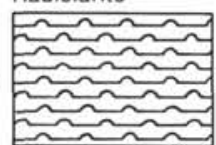

Porcellanite

$\Delta \Delta \Delta \Delta \Delta \Delta \Delta$

$\Delta \Delta \Delta \Delta \Delta \Delta$

B5 $\Delta \Delta \Delta \Delta \Delta \Delta \Delta$ SB6

$\Delta \Delta \Delta \Delta \Delta \Delta$

$\Delta \Delta \Delta \Delta \Delta \Delta \Delta$
Symbols that may be used for any new additions to the present sediment-rock groups. Assign number and letter in accordance with present system.

Basal sand of Hydrothermally graded beds altered sediment

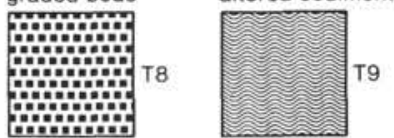

Cobbles of Rhythmically metamorphics laminated sections

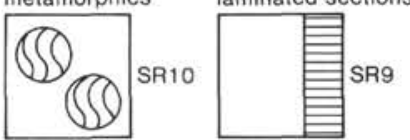

\section{Calcareous biogenic}

Pelagic biogenic calcareous - soft

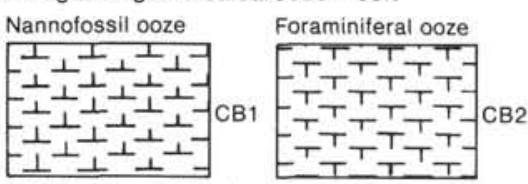

Pelagic biogenic calcareous - firm

\begin{tabular}{|c|c|c|c|}
\hline \\
\hline
\end{tabular}

Pelagic bioge

Limestone

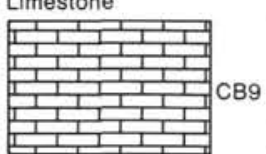

Foraminiferal chalk

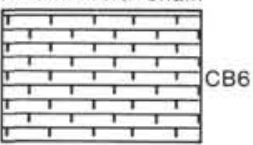

reous - hard

Transitional terrigenous -

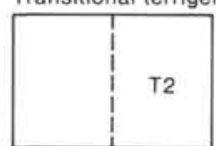

Nanno-foram or

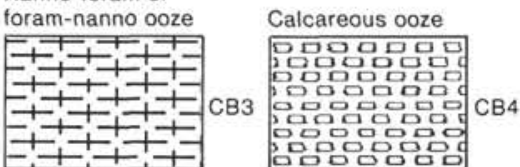

Chert

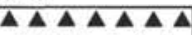

$\Delta \Delta \Delta \Delta \Delta \Delta$

$\Delta \Delta \Delta \Delta \Delta \Delta \Delta$ SB 7

$\Delta \Delta \Delta \Delta \Delta \Delta$

$\Delta \Delta \Delta \Delta \Delta \Delta \Delta$

\section{Specks and concretions}

(G) Glauconite

(S) Spiculite

(PH) Phosphate

(FD) Fish debris

(P) Pyrite

(A) Anhydrite

(E) Epidote

(D) Dropstone

(glacial erratic)

biogenic modifier with area

approximate according to abundance

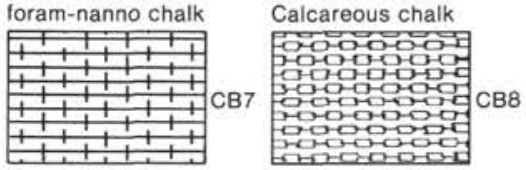

chedich

\section{דיבד}

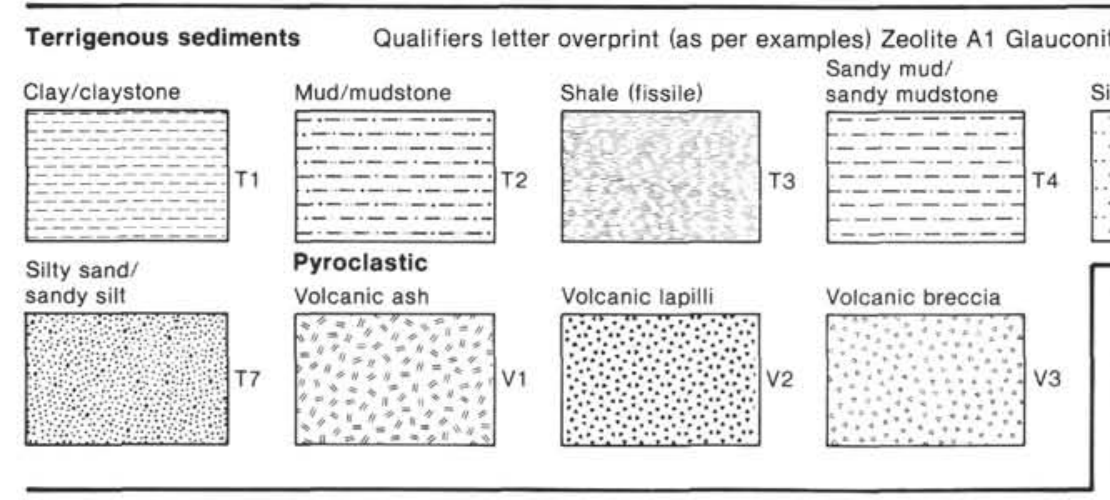

Special rock types

A3 Siderite A4 (other may be designated)
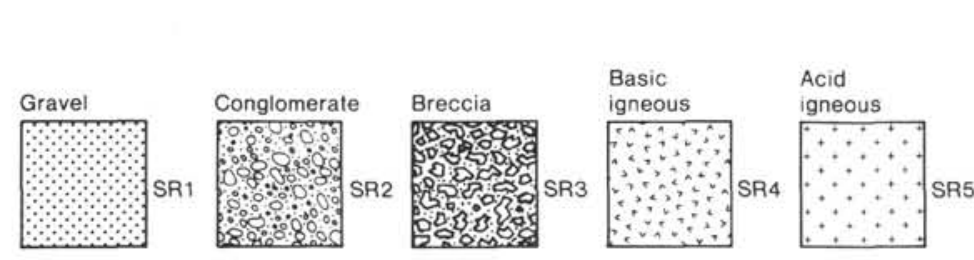

Carbonaceous
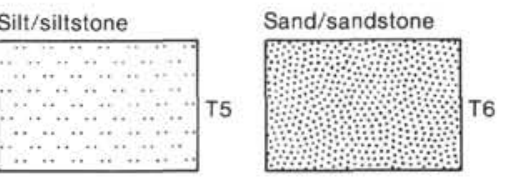

Figure 9. Symbols used in graphic lithology column of core description forms (sediments). 
dependently by different sedimentologists. However, attempts were made to be consistent throughout Volume 94.

Smear-slide percentages, thin-section descriptions, and carbonate content $\left(\% \mathrm{CaCO}_{3}\right)$ determined aboard ship are listed below the core description on these forms, where two numbers separated by a comma refer to the section and centimeter level of the sample, respectively. The locations of these samples in the core and a key to the codes used to identify these samples are given in the column headed "Samples" (Fig. 5). Locations and intervals of full round samples for organic geochemistry $(\mathrm{OG})$, interstitial water (IW), and physical properties (PP) are given in the lithologic column.

\section{Lithologic Classification of Sediments}

Most sediments recovered during Leg 94 (see section below) consist of either pelagic carbonate oozes or terrigenous mud. Colors are generally white to pale gray for the carbonate oozes and olive brown to gray for the terrigenous muds.

The basic classification system used was devised by the JOIDES Panel on Sedimentary Petrology and Physical Properties (SPPP) and was adopted for use by the JOIDES Planning Committee in March 1974. For the sake of continuity the Leg 94 shipboard scientists have used this basic classification. It is descriptive rather than genetic, and divisions between sediment types are arbitrary. A brief outline of the conventions and descriptive data used to classify sediments recovered on Leg 94 follows.

For the original JOIDES classification, see Volume 42, Pt. 2, of the Initial Reports (Ross, Neprochnov, et al., 1978, pp. 14-15).

\section{Composition and Texture}

In this classification, composition and texture are the only criteria used to define the type of sediment or sedimentary rock. These data come principally from shipboard visual estimates of smear slides using a petrographic microscope and are obtained by estimating the areal abundance and the size of components on the slide. The data are less reliable than shore-based analyses of grain size, carbonate content, and mineralogy (see specialty chapters, this volume), but provide rapid shipboard estimates for descriptive purposes. From past experience, quantitative estimates of distinctive minor components are accurate to within 1 or $2 \%$, but for major constituents accuracy is poorer $( \pm 10 \%)$ (Hsü, Montadert, et al., 1978). All smear-slide estimates were done aboard ship. The carbonate percentage of selected samples was determined using the carbonate bomb technique of Müller and Gastner (1971) as a check on the accuracy of smear-slide estimates for the descriptive logs. These values are listed on the core description forms below the lithologic description.

Grain size (texture) of terrigenous samples was estimated from smear slides and listed as percent sand-siltclay in the smear-slide summary on the core description forms. These estimates generally include terrigenous components only.
Where applicable, one or two modifiers were used in naming sediments. In all cases, the dominant component appears last in the name; minor components precede this, the least common being listed first. A minor constituent is included in the name if it represents at least $10 \%$ of the sediment. If a minor constituent of less than $10 \%$ is deemed significant it may be included in the name of the sediment or mentioned in the lithologic description.

\section{Induration of Sediments}

We recognize three classes of induration or lithification for calcareous sediments and sedimentary rocks in which the carbonate content is greater than $50 \%$, and two classes for other sedimentary types.

For calcareous sediments and sedimentary rocks (carbonate $>50 \%$ ), the three classes (after Gealy et al., 1971) are (1) soft-ooze (has little strength and is readily deformed under pressure of finger or broad blade of spatula); (2) firm-chalk (partially lithified and readily scratched with fingernail or edge of spatula); (3) hardlimestone, dolostone (well lithified and cemented).

For terrigenous sediments (terrigenous components $>50 \%$ ), the classes are (1) soft-sand, silt, clay, or combinations of these (readily deformed by finger or broad blade of spatula); (2) hard-sandstone, siltstone, claystone, and so on, that is, the suffix "-stone" is added (core must be cut with a band saw or diamond saw).

\section{Leg 94 Sediments}

Three main sediment types were recovered on Leg 94 . These sediments were classified as follows:

\section{Pelagic Biogenic Calcareous Sediments}

This sediment category is classified:

$\begin{array}{ll}\text { more than } 30 \% & \mathrm{CaCO}_{3} \\ \text { less than } 30 \% & \text { terrigenous components } \\ \text { less than } 30 \% & \text { siliceous microfossils }\end{array}$

Principal components are nannofossils and foraminifers with qualifiers used as follows:

\begin{tabular}{cl}
\hline Foraminifers (\%) & \multicolumn{1}{c}{ Name } \\
\hline Less than 10 & Nannofossil ooze \\
$10-25$ & Foraminiferal-nannofossil ooze \\
$25-50$ & Nannofossil-foraminiferal ooze \\
More than 50 & Foraminiferal ooze \\
\hline
\end{tabular}

Calcareous sediments containing 10 to $30 \%$ siliceous fossils carry the qualifier radiolarian, diatomaceous, or siliceous, depending upon the siliceous component(s).

\section{Transitional Biogenic Calcareous Sediments}

The second sediment type is classified:

$\begin{array}{ll}\text { more than } 30 \% & \mathrm{CaCO}_{3} \\ \text { more than } 30 \% & \text { terrigenous components } \\ \text { less than } 30 \% & \text { siliceous microfossils }\end{array}$


If the carbonate content is between 30 and $60 \%$, marly is used as a qualifier.

\section{Terrigenous Sediments}

The third sediment type is classified:

$\begin{array}{ll}\text { more than } 30 \% & \text { terrigenous components } \\ \text { less than } 30 \% & \mathrm{CaCO}_{3} \\ \text { less than } 30 \% & \text { siliceous microfossils } \\ \text { less than } 10 \% & \text { authigenic components }\end{array}$

Sediments in this category are subdivided into textural groups on the basis of the relative proportions of three grain-size components (sand-silt-clay). The size limits are those defined by Wentworth (1922). Textural classification is according to the triangular diagram shown in Figure 10 .

\section{Igneous Rocks}

The only igneous rocks recovered on Leg 94 were the basalts underlying sediments at King's Trough, Site 608 . These basalts were described in a general nature only, including several thin-section descriptions. They immediately follow the core descriptions for Hole 608.

\section{Physical Properties Methods}

Physical properties measured on sediments recovered during Leg 94 include shear strength, compressional wave velocity, continuous GRAPE wet-bulk density, as well as wet-bulk density, wet water content, dry water content, and porosity by conventional gravimetric techniques.

Shear-strength measurements were made on the sediments in split core liners using the motor-drive torvane. The axis of rotation of the vanes was perpendicular to the core axis during all measurements.

Compressional sonic velocities were measured at atmospheric pressure and at room temperature using a Hamilton Frame Velocimeter. Measurements were made perpendicular to the long core axis through the split core liner on soft sediments. Appropriate corrections were applied for an average liner thickness and the resulting traveltime. In more indurated sediments measurements were made on a piece of core taken out of the liner after splitting.

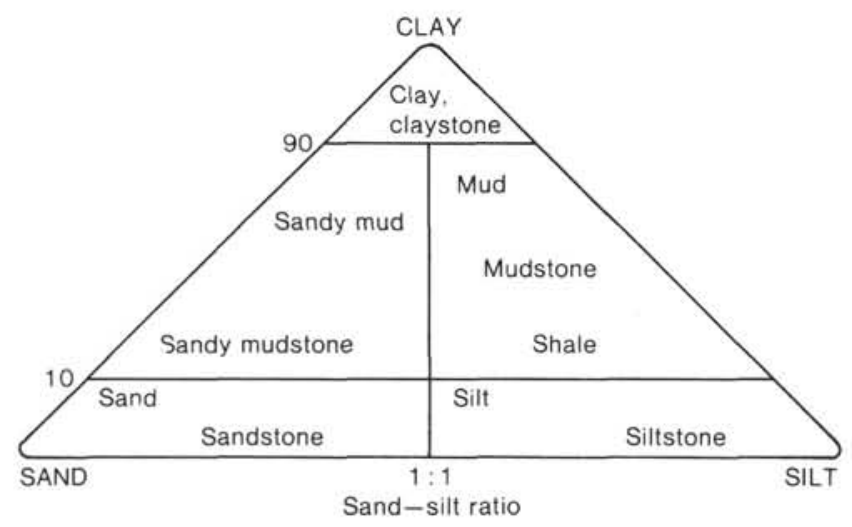

Figure 10. Textural groups of terrigenous sediments.
Continuous wet-bulk densities were measured by the GRAPE technique (Gamma Ray Attenuation Porosity Evaluation). In this technique porosity is measured by passing gamma rays through the sediment. Wet-bulk density is then calculated by assuming a value of $2.7 \mathrm{~g} / \mathrm{cm}^{3}$ for grain density. For description of all physical properties methods used aboard Glomar Challenger, see Boyce (1976a, b).

\section{Paleomagnetic Methods}

The successful recovery on Leg 94 of long, undisturbed sequences of sediment using the HPC and XCB corers yielded sections ideally suited for magnetostratigraphic study. The high sedimentation rates, averaging between 50 and $60 \mathrm{~m} / \mathrm{m}$.y., allowed a sampling interval of $1.5 \mathrm{~m}$, which clearly defined the magnetic polarity chronozones, but additional sampling at a 0.75 - $\mathrm{m}$ interval was occasionally required to further define the boundaries of subchronozones with a duration of 0.05 m.y. or less.

Paleomagnetic samples were taken by pressing oriented, $7-\mathrm{cm}^{3}$ plastic cubes into the split half of the core. When the sediment became too stiff to allow the use of plastic boxes, $3.5-\mathrm{cm}$-diameter cores were drilled from the split half of the core using a drill press with a diamond drill bit.

Pilot samples selected from intervals of varying lithology throughout the length of each hole were subjected to progressive alternating field demagnetization studies at increments of 5 to $10 \mathrm{mT}$. On the basis of the results of these studies, the remaining samples from the core were partially demagnetized at the field determined to be necessary to remove unstable or secondary magnetizations.

The directions and magnitude of the magnetizations of the samples were measured using a portable "Molspin" spinner magnetometer. This magnetometer was preferred over the shipboard "Digico" magnetometer, as the "Digico" exhibited a significantly higher instrumental noise level than the Molspin.

The Custer orientation tool (Weinreich and Theyer, 1985) was not used routinely on the cores taken on Leg 94. For that reason the declinations between cores were not consistent, and therefore the inclination record alone was used to determine the polarity sequence. The high latitudes of the sites $\left(35-53^{\circ} \mathrm{N}\right)$ provided steep inclinations \pm 55 to $\pm 70^{\circ}$ ) so that normal and reversed polarity zones were readily identifiable based solely on the inclination records.

\section{Time Scale}

The time scales of Berggren, Kent, and Flynn and Berggren, Kent, and Van Couvering (in press) (Table 2, Fig. 11) were used as the chronological framework for the Leg 94 Initial Reports. We adhere to the most recent version of this scale by utilizing an Anomaly 5-Chron 11 correlation rather than the previous Anomaly 5-Chron 9 correlation. This results in generally younger absolute ages for late middle and early late Miocene microfossil zones and datum levels. Calibration of diatom events to magnetostratigraphy is after Barron et al. (1985). 
Table 2. Revised geomagnetic polarity time scale ${ }^{a}$ for $\mathrm{Ce}$ nozoic and Late Cretaceous time.

\begin{tabular}{|c|c|c|c|}
\hline $\begin{array}{c}\text { Normal polarity } \\
\text { interval } \\
(\mathrm{Ma})\end{array}$ & Anomaly & $\begin{array}{l}\text { Normal polarity } \\
\text { interval } \\
(\mathrm{Ma})\end{array}$ & Anomaly \\
\hline $0.00-0.73$ & 1 & $20.88-21.16$ & $6 \mathrm{~A}$ \\
\hline $0.91-0.98$ & & $21.38-21.71$ & $6 \mathrm{~A}$ \\
\hline $1.66-1.88$ & 2 & $21.90-22.06$ & \\
\hline $2.47-2.92$ & $2 \mathrm{~A}$ & $22.25-22.35$ & \\
\hline $2.99-3.08$ & $2 \mathrm{~A}$ & $23.27-23.44$ & $6 \mathrm{C}$ \\
\hline $3.88-3.97$ & 3 & $23.55-23.79$ & $6 \mathrm{C}$ \\
\hline $4.10-4.24$ & 3 & $24.04-24.21$ & $6 \mathrm{C}$ \\
\hline $4.40-4.47$ & 3 & $25.50-25.60$ & 7 \\
\hline $4.57-4.77$ & 3 & $25.67-25.97$ & 7 \\
\hline $5.35-5.53$ & $3 \mathrm{~A}$ & $26.38-26.56$ & $7 \mathrm{~A}$ \\
\hline $5.68-5.89$ & $3 \mathrm{~A}$ & $26.86-26.93$ & 8 \\
\hline $6.37-6.50$ & & $27.01-27.74$ & 8 \\
\hline $6.70-6.78$ & 4 & $28.15-28.74$ & 9 \\
\hline $6.85-7.28$ & 4 & $28.80-29.21$ & 9 \\
\hline $7.35-7.41$ & 4 & $29.73-30.03$ & 10 \\
\hline $7.90-8.21$ & $4 \mathrm{~A}$ & $30.09-30.33$ & 10 \\
\hline $8.41-8.50$ & $4 \mathrm{~A}$ & $31.23-31.58$ & 11 \\
\hline $8.71-8.80$ & & $31.64-32.06$ & 11 \\
\hline $8.92-10.42$ & 5 & $32.46-32.90$ & 12 \\
\hline $10.54-10.59$ & & $35.29-35.47$ & 13 \\
\hline $11.03-11.09$ & & $35.54-35.87$ & 13 \\
\hline $11.55-11.73$ & $5 \mathrm{~A}$ & $37.24-37.46$ & 15 \\
\hline $11.86-12.12$ & $5 \mathrm{~A}$ & $37.48-37.68$ & 15 \\
\hline $12.46-12.49$ & & $38.10-38.34$ & 16 \\
\hline $12.58-12.62$ & & $38.50-38.79$ & 16 \\
\hline $12.83-13.01$ & & $38.83-39.24$ & 16 \\
\hline $13.20-13.46$ & & $39.53-40.43$ & 17 \\
\hline $13.69-14.08$ & & $40.50-40.70$ & 17 \\
\hline $14.20-14.66$ & & $40.77-41.11$ & 17 \\
\hline $14.87-14.96$ & $5 \mathrm{~B}$ & $41.29-41.73$ & 18 \\
\hline $15.13-15.27$ & $5 B$ & $41.80-42.23$ & 18 \\
\hline $16.22-16.52$ & 5C & $42.30-42.73$ & 18 \\
\hline $16.56-16.73$ & $5 \mathrm{C}$ & $43.60-44.06$ & 19 \\
\hline $16.80-16.98$ & $5 \mathrm{C}$ & $44.66-46.17$ & 20 \\
\hline $17.57-17.90$ & 5D & $48.75-50.34$ & 21 \\
\hline $18.12-18.14$ & 5D & $51.95-52.62$ & 22 \\
\hline $18.56-19.09$ & $5 \mathrm{E}$ & $53.88-54.03$ & 23 \\
\hline $19.35-20.45$ & 6 & $54.09-54.70$ & 23 \\
\hline $55.14-55.37$ & 24 & $66.74-68.42$ & 30 \\
\hline $55.66-56.14$ & 24 & $68.52-69.40$ & 31 \\
\hline $58.64-59.24$ & 25 & $71.37-71.65$ & 32 \\
\hline $60.21-60.75$ & 26 & $71.91-73.55$ & 32 \\
\hline $63.03-63.54$ & 27 & $73.96-74.01$ & \\
\hline $64.29-65.12$ & 28 & $74.30-80.17$ & 33 \\
\hline $65.50-66.17$ & 29 & 84.00 & 34 \\
\hline
\end{tabular}

The adoption of this time scale and the absolute age estimates of the microfossil datums is preliminary, as the biostratigraphic and paleomagnetic results of Leg 94 indicate that biostratigraphic events are often diachronous between sites. Re-evaluation of the biostratigraphic events and paleomagnetic correlation for the mid- to high-latitude North Atlantic Ocean is discussed in the biostratigraphic synthesis (Baldauf et al., this volume).

\section{Calcareous Nannofossils}

Zonation scheme: Martini (1971)

Correlation to polarity scale: Poore et al. (1984), Haq and Takayama (1984), between NN15 and NN9.

\section{Planktonic Foraminifers}

Zonation scheme: Berggren (1973, 1977), Blow (1959), Jenkins (1971), Jenkins and Srinivasan (1984).

Correlation to polarity scale: Berggren et al., 1984.

\section{Diatoms}

Zonation scheme: Burckle (1972), Baldauf (1984), Barron (1985).

Correlation to polarity scale: Burckle $(1972,1977)$, Barron et al. (1985).

\section{Radiolarians}

Zonation scheme: Riedel and Sanfilippo (1978) Sphaeropyle langii Zone (Foreman, 1975), base of zone (Casey and Reynolds, 1980).

Correlation to polarity scale: Theyer et al., 1978.

\section{Geochemical Methods}

Interstitial water samples were obtained using the hydraulic press apparatus described by Whitmarsh et al. (1974). The water samples were analyzed for salinity using an American Optical Company temperature-compensated refractometer, and $\mathrm{pH}$ was measured using a Corning $130 \mathrm{pH}$ meter with a Markson electrode. Two Wescan Ion Chromatographs were used to determine $\mathrm{K}^{+}$, $\mathrm{Li}^{+}, \mathrm{Ca}^{2+}, \mathrm{Mg}^{2+}$, and $\mathrm{SO}_{4}^{2-}$. New high-speed columns were used in the chromatographs to (1) make the analyses less time consuming, and (2) facilitate calibration of $\mathrm{Mg}^{2+}$, which during previous legs yielded a nonlinear calibration curve.

The concentration of $\mathrm{CaCO}_{3}$ in sediment samples was determined using a modified carbonate bomb (Müller and Gastner, 1971). This method involves treating a powdered sample with $\mathrm{HC} 1$ in a closed cylinder. The resulting pressure of $\mathrm{CO}_{2}$ is proportional to the carbonate $\left(\mathrm{CaCO}_{3}\right)$ content of the sample, and this value is converted to percent $\mathrm{CaCO}_{3}$, using the calibration factor of the manometer. The accuracy of this method is believed to be $\pm 5 \%$ (Hsü, Montadert, et al., 1978).

Although carbon measurements were not a major objective of Leg 94, recent repairs to the LECO carbon analyzer required assessment. Various calibrations and crosscalibrations of the LECO system with the HP185B CHN analyzer and carbonate-bomb methods were carried out when opportunities arose.

\section{REFERENCES}

Baldauf, J. G., 1984. Cenozoic diatom biostratigraphy and paleoceanography of the Rockall Plateau Region, North Atlantic, Deep Sea Drilling Project Leg 81. In Roberts, D. G., Schnitker, D., et al., Init. Repts. DSDP, 81: Washington (U.S. Govt. Printing Office), 439-477.

Barron, J. A., 1985. Neogene planktic diatom biostratigraphy. In Bolli, H. M., Saunders, J. B., and Perch-Nielsen, K. (Eds.), Plankton Stratigraphy: Cambridge, U.K. (Cambridge University Press), pp. 763-809.

Barron, J. A., Keller, G., and Dunn, D. 1985. A multiple microfossil biochronology for the Miocene. In Kennett, J. P. (Ed.), The Miocene Ocean: Paleoceanography and Biogeography: Geol. Soc. Am. Mem., 163:21-36.

Berggren, W. A., 1973. The Pliocene timescale calibration of planktonic foraminiferal and calcareous nannoplankton zones. Nature, 243:391-397.

1977. Late Neogene planktonic foraminiferal zonation of the Rio Grande Rise (South Atlantic). Mar. Micropaleontol., 2: 251-265.

Berggren, W. A., Kent, D., and Flynn, J. L., in press. Paleogene geochronology and chronostratigraphy. In Snelling, N. J. (Ed.), Geochronology and the Geological Record. J. Geol. Soc. London Mem.

Berggren, W. A., Kent, D., and Van Couvering, J. A., in press. Neogene geochronology and chronostratigraphy. In Snelling, N. J. (Ed.), 
Geochronology and the Geological Record. J. Geol. Soc. London Mem.

Blow, W., 1959. Age, correlation and biostratigraphy of the upper Tucuyo (San Lorenzo) and Pozon Formations, Eastern Falcon, Venezuela. Bull. Am. Paleontol., 39(178):59.

Boyce, R. E., 1976a. I. Definitions and laboratory techniques of compressional sound velocity parameters and wet-water content, wetbulk density, and porosity parameters by gravimetric and gamma ray attenuation techniques. In Schlanger, S. O., Jackson, E. D., et al., Init. Repts. DSDP, 33: Washington (U.S. Govt. Printing Office), 931-958.

1976b. Deep Sea Drilling Project procedures for shear strength measurements of clayey sediments using modified Wykeham Farrance Laboratory van apparatus. In Barker, P. F., Dalziel, I. W. D., et al., Init. Repts. DSDP, 36: Washington (U.S. Govt. Printing Office), 633-670.

Burckle, L. H., 1972. Late Cenozoic planktonic diatom zones from the eastern equatorial Pacific. Nova Hedwigia Beihefte, 39:217-246. , 1977. Pliocene and Pleistocene diatom datum levels from the equatorial Pacific. Quat. Geol.. 7:330-340.

Casey, R. E., and Reynolds, R. A., 1980. Late Neogene radiolarian biostratigraphy related to magnetostratigraphy and paleoceanography with suggested cosmopolitan radiolarian datums. Cushman Found. Spec. Publ., 19:287-300.

Foreman, H. P., 1975. Radiolaria from the North Pacific, DSDP Leg 32. In Larson, R. L., Moberly, R., et al., Init. Repts. DSDP, 32: Washington (U.S. Govt. Printing Office), 579-676.

Gealey, E. L., Winterer, E. L., and Moberly, R., 1971. Methods, conventions, and general observations. In Winterer, E. L., Riedel, W. R., et al., Init. Repts. DSDP, 7, Pt. 1: Washington (U.S. Govt. Printing Office), 9-26.

Haq, B. U., and Takayama, T., 1984. Neogene calcareous nannoplankton datum planes and their calibration to magnetostratigraphy. Proc. Pacific Neogene Datum Planes Workshop, Osaka, 1981, pp. 27-33.

Hsü, K. J., Montadert, L., et al., 1978. Init. Repts. DSDP, 42, Pt. 1: Washington (U.S. Govt. Printing Office).

Jenkins, D. G., 1971. New Zealand Cenozoic planktonic foraminifera. N. Z. Geol. Survey Paleontol. Bull., 42.

Jenkins, D. G., and Srinivasan, M. S., 1986. Cenozoic planktonic foraminifers from the equator to the Sub-Antarctic of the southwest Pacific. In Kennett, J. P., von der Borch, C. C., et al., Init. Repts. DSDP, 90, Pt. 2: Washington (U.S. Govt. Printing Office), 795834.

Kennett, J. P., von der Borch, C. C., et al., 1986. Init. Repts. DSDP, 90: Washington (U.S. Govt. Printing Office).
Kidd, R. B., Searle, R. S., Ramsay, A. T. S., Pritchard, H., and Mitchell, J., 1982. The geology and formation of King's Trough, northeast Atlantic Ocean. Mar. Geol., 48:1-30.

Martini, E., 1971. Standard Tertiary and Quaternary calcareous nannoplankton zonation. Proc. Second Planktonic Conf. Roma, 1970, 2:739-785.

Mayer, L., Theyer, F., et al., 1985. Init. Repts. DSDP, 85: Washington (U.S. Govt. Printing Office).

Morley, J. J., and Shackleton, N. J., 1978. Extension of the radiolarian Stylatracta universus as a biostratigraphic datum to the Atlantic Ocean. Geology, 6:309-311.

Müller, G., and Gastner, M., 1971. The "Karbonate Bombe," a simple device for the determination of carbonate content in sediments, soils and other material. Neues Jahrb. Mineral. Monatsh., 10:466469.

Okada, H., and Burkry, D., 1980. Supplementary modification and introduction of code numbers to the low-latitude coccolith biostratigraphic zonation (Bukry, 1973: 1975). Mar. Micropaleontol., 5:321-325.

Poore, R. Z., Tauxe, L., Percival, S. F., LaBrecque, J., Wright, R., et al., 1984. Late Cretaceous-Cenozoic magnetostratigraphic and biostratigraphic correlations for the South Atlantic Ocean, DSDP Leg 73. In Hsü, K., LaBrecque, J., et al., Init. Repts. DSDP, 73: Washington (U.S. Govt. Printing Office), 645-656.

Prell, W. L., Gardner, J. V., et al., 1982. Init. Repts. DSDP, 68: Washington (U.S. Govt. Printing Office).

Riedel, W. R., and Sanfilippo, A., 1978. Stratigraphy and evolution of tropical Cenozoic radiolarians. Micropaleontology, 24:61-96.

Ross, D. A., and Neprochnov, Y. P., et al., 1978. Init. Repts. DSDP, 42, Pt. 2: Washington (U.S. Govt. Printing Office).

Theyer, F., Mato, C. Y., and Hammond, S. R., 1978. Paleomagnetic and geochronologic calibration of latest Oligocene to Pliocene radiolarian events, Equatorial Pacific. Mar. Micropaleontol., 3:377395.

Weinreich, N., and Theyer, F., 1985. Paleomagnetism of DSDP Leg 85 sediments: Neogene magnetostratigraphy and tectonic history of the central equatorial Pacific Ocean. In Mayer, L., Theyer, F., et al., Init. Repts. DSDP, 85: Washington (U.S. Govt. Printing Office), 849-901.

Wentworth, C. K., 1922. Scale of grade and class terms of clastic sediments. J. Geol., 30:377-392.

Whitmarsh, R. B., Weser, O. E., and Ross, D. A., 1974. Introduction. In Whitmarsh, R. B., Weser, O. E., and Ross, D. A., Init. Repts. DSDP, 23: Washington (U.S. Govt. Printing Office), 5-9. 


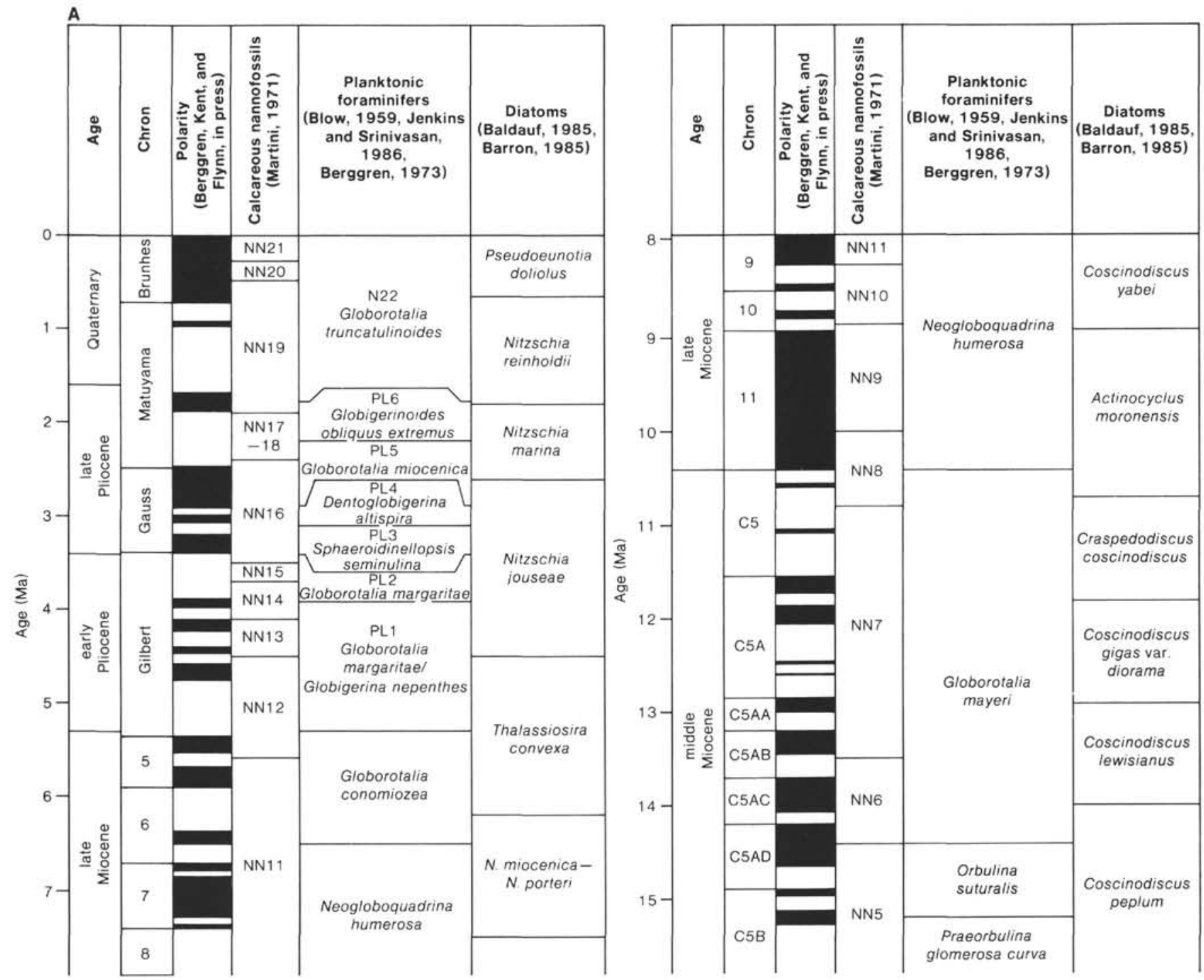

Figure 11. Time scale used during Leg 94. (See Baldauf et al. [this volume] for updated version.) A. Neogene. B. Paleogene. Note difference in scale. 
INTRODUCTION, BACKGROUND, AND EXPLANATORY NOTES
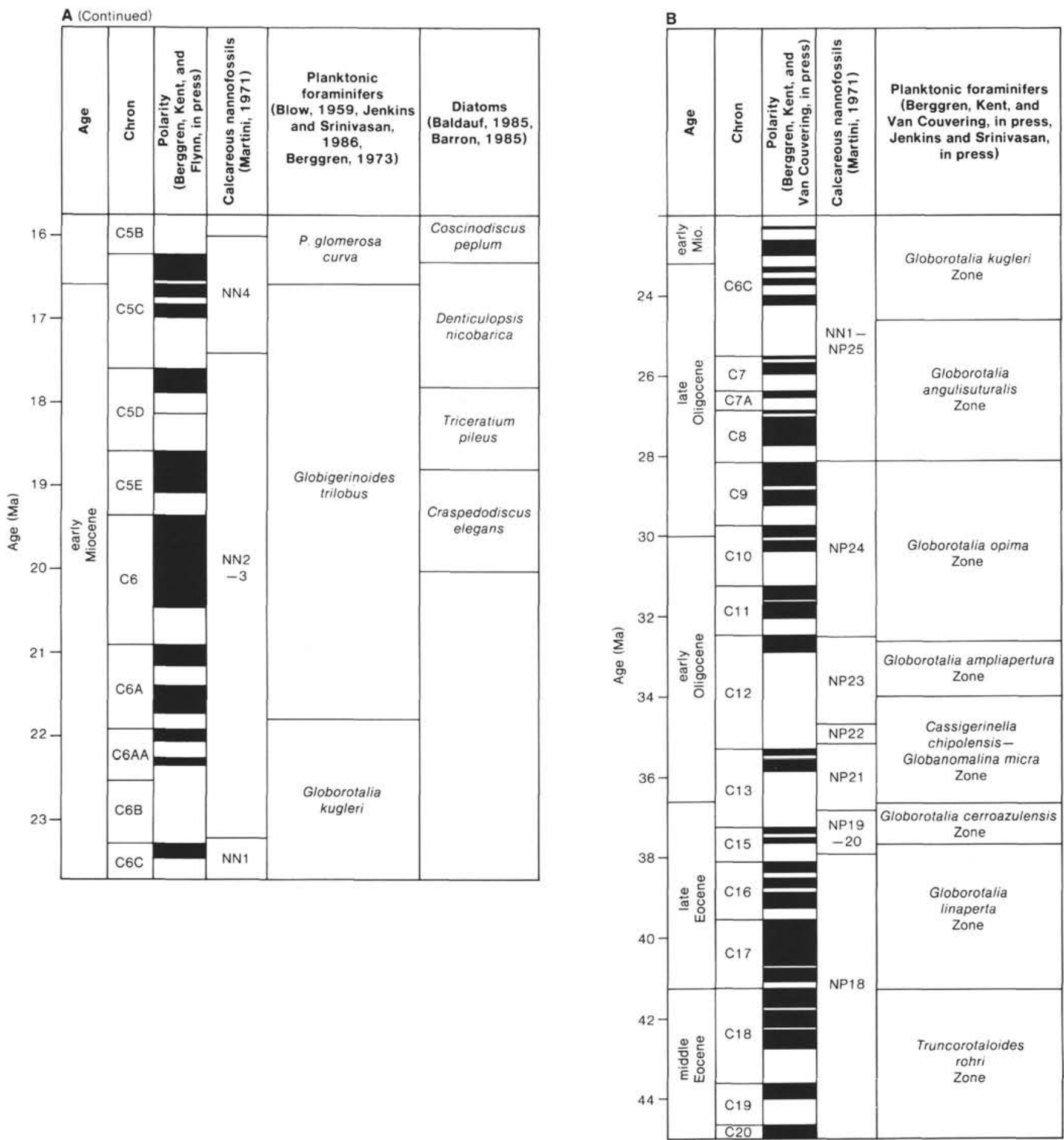

Figure 11 (continued). 